18. Vodolazskiy, V. T. (1980). O pokazatelyah stepeni metamorfizma kamennyih ugley Donbassa. Ugol Ukrainyi, 6, 35-36.

19. Avgushevich, I. V., Sidoruk, E. I., \& Bronovets, T. M. (2019). Standartnyie metodyi ispyitaniya ugley. Klassifikatsii ugley. Moskva: «Reklama master»».

20. Vodolazskiy, V. T. (1980). Svyaz glubinyi gazovogo vyivetrivaniya s uglom zaleganiya plastov i ih metamorfizmom. Ugol Ukrainyi, 1, 38.

21. Antoschenko, N. I., \& Tomalak, N. V. (2002). Vliyanie temperaturyi na stepen metamorfizma iskopaemyih ugley. Ugol Ukrainyi, 7, 36-38.

https://doi.org/10.31713/m1011

\title{
RESULTS OF PHYSICO-CHEMICAL STUDIES OF ORE ROCKS AND ELEBARATION THEWAY OF EXTRACT USEFUL COMPONENTS FROM THEM
}

\section{Toktosunova B.}

Kyrgyz State University of Geology, Mining and Natural Resources Exploitation named after Academician U.Asanaliev (KGGU), Doctor of Chemistry, Professor, Head of the "Natural Sciences", Kyrgyzstan

\section{Sultankulova A.}

Kyrgyz-Russian Slavic University named after B. N. Yeltsin (KRSU), Candidate of Chemical Sciences, Associate Professor, Leading Researcher, Kyrgyzstan

\section{Kushnazarova S.Z.}

Kyrgyz Institute of Mineral Resources (KIMR), Researcher, Kyrgyzstan

\section{Aitkulov B.T.}

Kyrgyz Institute of Mineral Resources (KIMR), Researcher, Kyrgyzstan

\section{Toktosunov N.M.}

Kyrgyz Institute of Mineral Resources (KIMR), Researcher, Kyrgyzstan

\section{Annotation}

This paper work determinesthe results of research on the physico-chemical properties of ore minerals from the deposits of the Sarijaz Ore Area of the Berkutsk Group of the Kyrgyz Republic.Mechanical processing of test minerals according to known method was carried out.The influence of particle dispersion in test samples on the expression of some metals in ore minerals has been studied.The effect of the 
sample size on the yield of the useful components has been determined.It is shown that in a finely fragmented sample the output of the noble metal is several times higher than the control metal.

Keywords: ore, crushing, lyddite, dispersion, spectral and elemental analysis, coarse and fine fraction, raster electron microscope.

\section{Introduction}

Chemical and technological research into ore minerals, the identification of useful components therein and the search for netmethods for recovering them from ores are priorities in mining.In this context, carbon-silicon shale (UKS) and the Berkut group lyddite of the Sarijaz ore region of the Kyrgyz Republic are promising subjects for detailed study. Early studies have provided that the ores in this area contain rare $(\mathrm{V}, \mathrm{Mo}, \mathrm{Bi}$, etc.), noble $(\mathrm{Ag}, \mathrm{Au}, \mathrm{Pt}, \mathrm{Pd})$, etc. Metals with signs of graphite and diamond (fullerit) particulates [1-6].

In addition, during the exploration of the facility, a number of additional non-metallic industrial products were identified, moreover to metallic components, such as elemental silicon, silicon carbide, graphite, abrasives and refractory lining materials for civil applications industrial construction; high resistance colorants , commercial decorative stones for construction and architecture. ScientificResearches have been carried out on the possibility of using Kyrgyz lyddite in the development of new types of refractory and chemically resistant material.

However, the mineral resources of the Sarijaz Ore Area remain poorly studied, so new data on their formation, distribution, feasibility and prospects for industrial platinum concentration are periodically available, palladium and other platinum metals.(PMG)However, owing to the lack of efficient processing technology, it has not been possible to fully separate the valuable components of ore rocks from tailings . Consequently, research work into the useful components of lyddite and how to extract them from it is highly relevant [7].

Consistent with the objective set out belowthe purpose of this research is to study the physico-chemical characteristics of the lyddite and to identify useful components therein, as well as to find ecologically renewable and clean methods of extracting them. 
Examination of the structure and texture of the ore mineral under study by a raster electron microscope

\section{Objects of research}

The samples of lyddite from the Berkutsky field were taken for:

- research into the type of mineral ores;

- withdrawing the characteristics of the ore

- study of texture-morphological structures.

According to the purpose of the research, texture fragments were selected for the manufacture of polished knobs.Dimensions of the samples were: polished Anschliff $-2.5 \mathrm{~cm}$, and coarsely $(>0.5 \mathrm{~cm})$ and finely $(<0.01 \mathrm{~cm})$ shredded.

\section{Materials and methods of research}

One type of ore mineral with different textures was studied: the material for analytical studies wasfine-dyspersated, large-grained and pieces of lyddite. (Figure 1.)

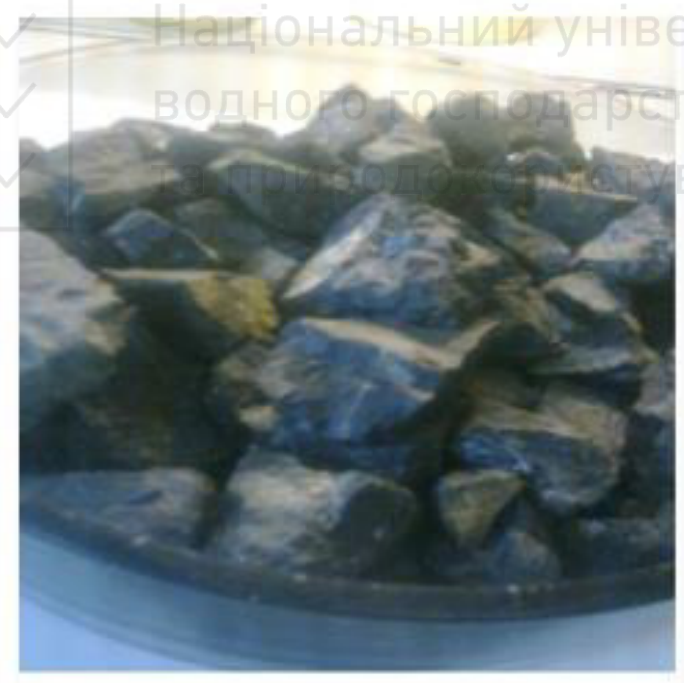

Figure 1. Crushed Lidite Lumps

The preparation of samples and the choice of the mode of operation of the SEM have been conducted in accordance with the known method [8]. 


\section{Resultsand discussion for the research.}

It is known [9] that the structure and texture of the ore give an indication of the sequence of extraction of minerals and mineral associations and subsequent changes in them. The structure of the ore and the composition of the paragenetic associations of minerals may indirectly indicate all the conditions (temperature, pressure, time of formation and starting material) at which ore was deposited or altered. Structural texture of the ore is therefore important in determining the genesis and explaining the subsequent geological history of the mineral deposit.In this work, the characteristic texturestructure characteristics of the mineral being studied are identified by SEM image analysis.

The fragment of the ore mineral in Figure 2 confirms that there is no spatial reference of the grains in any one primary direction.

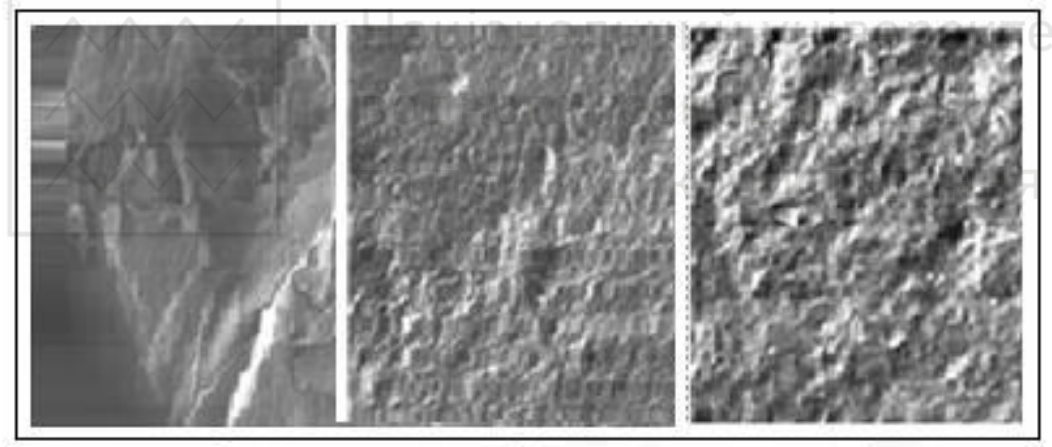

a)

b)

c)

Fig.2. Morphological and structural features of the studied polished section of the mineral

Ore mineral fragment

a) magnification $x 46$ (widch 6.23 microns)

b) magnification $\times 490$ (widch 595 microns)

c) magnification xl020 (widch 296 microns)

The sample also shows the high density and density, no cavities and voids. Therefore, this fragment makes it possible to definitive statement aboutthat the rock consists of one mineral, i.e. it has a uniform massive and uniform structure. By increasing the same fragment, the structure of the mineral being studied shows that the 
mineral is due to the shape and nature of the fusion of mineral grains (Figures $\mathbf{2} \boldsymbol{a}, \boldsymbol{b}$ and $\boldsymbol{c}$, respectively).

The following is the analysis of electronic images of ground mineral samples. It is well known that rock disintegration has different objectives.[10-11]. The fundamental objective is to release a valuable component from tailings, to uncover it. Nevertheless, the morphological-structural features of the mineral are highly dependent on the way the ore is destroyed.Because grinding fails to uncover ore minerals because of their extremely small size and thin sprouting with non-metallic minerals. Accordingly, in the context of the abovehypotheses, the morphology of the experimental mineral after grinding has been studied.(Figures $\mathbf{3} \boldsymbol{a}, \boldsymbol{b}, \boldsymbol{c}$ ).

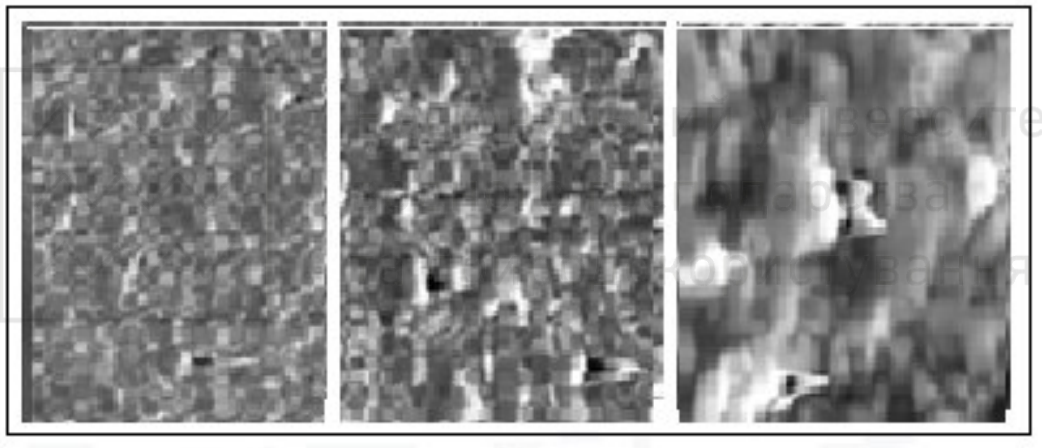

a)

b)

c)

Fig.3. Morphological and structural features fine fraction of the studied natural mineral

Fragment of ore mineral LT-2-SM

(fine fraction) SEM

a) magnification $\times 410$ (widch 582 microns)

b) magnification $\times 1010$ (widch 248 microns)

c) magnification $x$. 4000 (widch 61.5 microns)

The structure of the ore mineral is homogeneityin mass and structure. In addition, in the drawings «magnetite» inclusions are noticed, as evidenced by electrolysis of samples. 
The photographs of the mineral shown in Figures $4 \boldsymbol{a}, \boldsymbol{b}$, and $\boldsymbol{c}$ suggest that the mineral is characterized by a clastic structure.

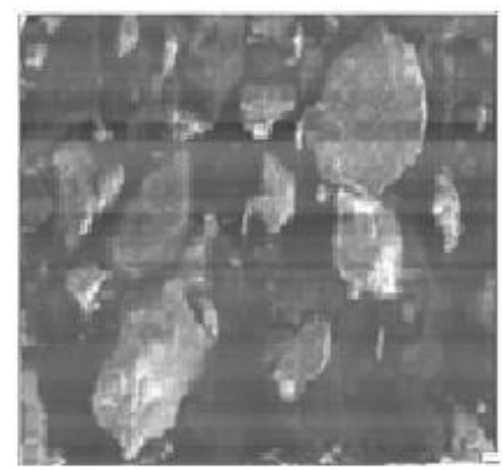

a)

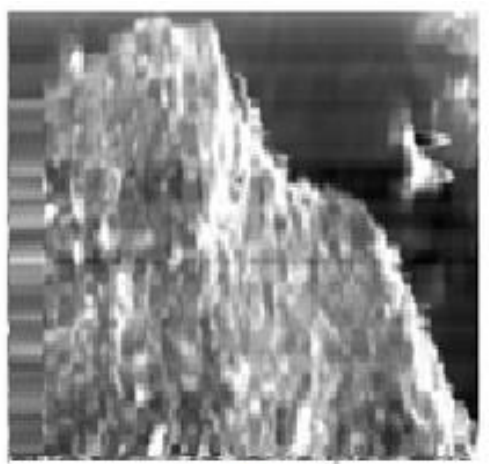

b)

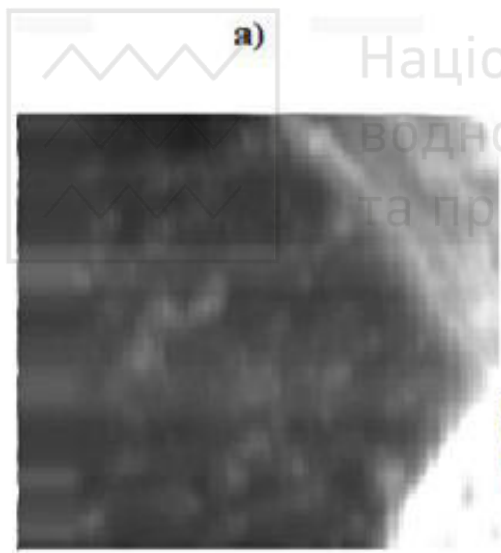

Fig.4. Morphological and structural features of the coarse fraction of the studied natural mineral Fragment of ore mineral LT-1-G (coarse fraction) SEM

a) magnification $x 78$ (width 3.07 microns)

b) magnification $x 1010$ (width 253 microns)

c) magnification $x \mathbf{3 6 0 0}$ (width 69.3 microns)

c)

The image magnification [x1010 (width 253 sm)] and [x4000 (width $61.5 \mathrm{sm}$ )] indicate that the mineral is evenly grained, nonporous and does not include (figures $\mathbf{5} \boldsymbol{a}, \boldsymbol{b}$ and $\boldsymbol{c}$ ). 


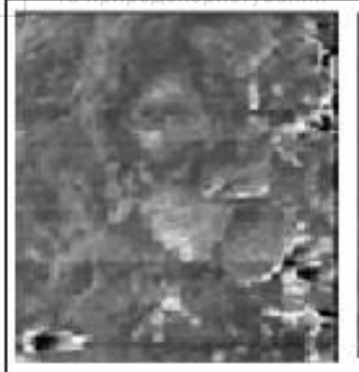

a)



b)



c)

Fig.5. Morphological and structural features of the coarse fraction of the studied natural mineral . Fragnent of ore mineral LT-1-G (coarse fraction) SEM

a) magnification $x 99$ (widch 2,5 microns)

b) magnification $x 1010$ (widch 246 microns)

c) magnification $x 4000$ (widch 60,6 microns)

Images $\mathbf{6} \boldsymbol{a}, \boldsymbol{b}$ and $\mathbf{c}$ show no layering, even microlayering, and no overlapping veins. The dark grey «pebbled surface» (fragment $\boldsymbol{b}$ ), i.e. the surface of the mineral looks rough - shallow (with dark spots).



a)

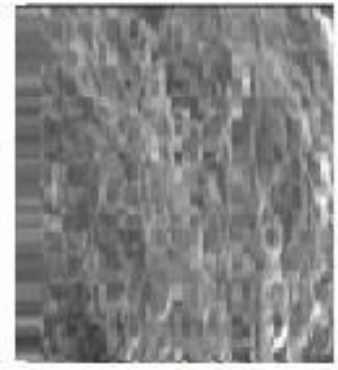

b)



c)

Fig.6. Morphological and structural features of the coarse fraction of the studied natural mineral . Fragnent of ore mineral LT-1-G (coarse fraction) SEM

a) magnification $x 41$ (widch 5.67 microns)

b) magnification $x 1010$ (widch 252 microns)

c) magnification $x$. 1800 (widch 139,4 microns) 
Analyses of electron-morphological images suggest that the ore studied refers to minerals of «moderate magnetism», the texture of the mineral is massive and the structure is hidden crystal. That has been proven by scientific data, specifically «The latent crystal structure is characterized by fine grained formation of minerals whose grains are indistinguishable by the eye».

\section{Examination of chemical composition}

Samples from the Sarijaz field (115-L and 116-L) were shredded and spectrally analyzed. The results are presented in table 1 .

Spectral analysis of reference samples from the Sarijaz deposit

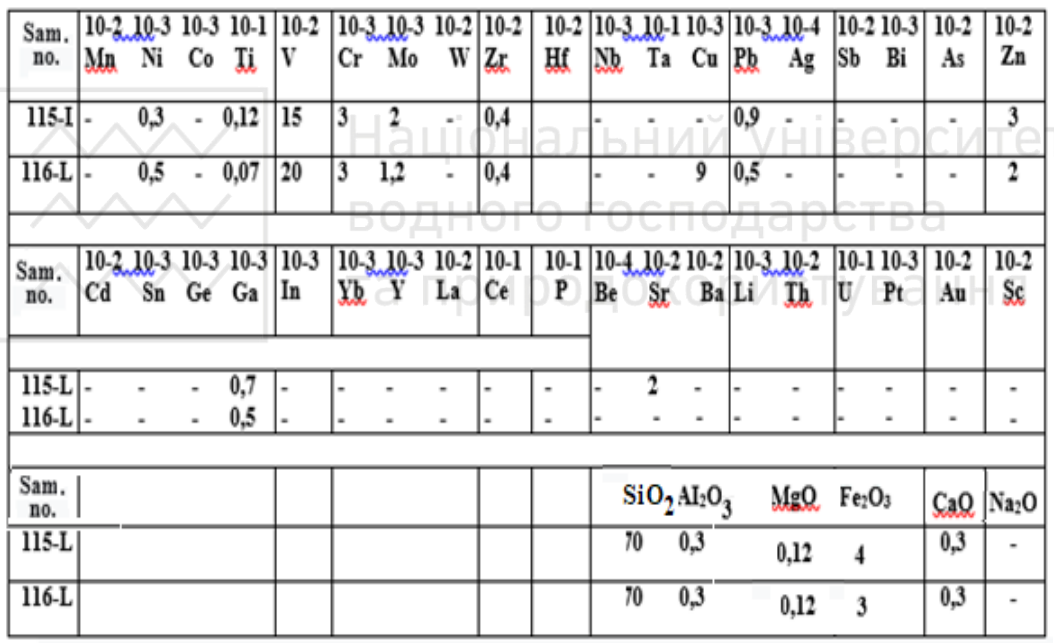

The Table indicates that the majority of iron oxide content $\left(\mathrm{Fe}_{2} \mathrm{O}_{3}\right)$ in samples $(115-\mathrm{L})$ is $4 \%$ and $(116-\mathrm{L}) 3 \%$. This quantity of iron oxide is also confirmed in the mechanical separation of $\mathrm{Fe}_{2} \mathrm{O}_{3}$.

Furthermore, to examine theeffect of the size of the dispersed particles on the metal in ores, the experimental samples were roughly grinded at a crushing plant at a pressure of 30-60 atm $/ \mathrm{cm} 2$.Spectral analysis of the fine particle of the lyddite sample are presented in Table 2 
Spectral analysis of dispersed lyddite samples from the Sarijaz field

\begin{tabular}{|c|c|c|c|c|c|c|c|c|c|c|c|c|c|c|}
\hline Sam. & $\begin{array}{llll}10-2 & 10-3\end{array}$ & $10-3$ & $10-1$ & $10-2$ & $10-3$ & $10-3$ & $\begin{array}{lll}10-2 & 10-2\end{array}$ & $10-2$ & $10-3$ & $\mid 10-1$ & $10-310^{3}$ & $10-4$ & $10-210$ & $\begin{array}{llll}3 & 10-2 & 10-2\end{array}$ \\
\hline no. & $\mathrm{Mn} \quad \mathrm{Ni}$ & $\mathrm{C}_{0}$ & $\mathrm{Ti}$ & & $\mathrm{Cr}$ & Mo & W $\quad \mathrm{Zr}$ & Hf & $\mathrm{Nb}$ & Ta & $\mathrm{Cu} \quad \mathrm{Pb}$ & $\mathrm{Ag}$ & $\mathrm{Sb} \quad \mathrm{Bi}$ & As $\mathrm{Zn}$ \\
\hline CF & 0,3 & 0,3 & 0,2 & 5 & 5 & 0,9 & $\begin{array}{ll}0,3 & 0,4\end{array}$ & - & 2 & & 30 & 15 & - & $-1,2$ \\
\hline $\mathrm{SF}$ & 0,3 & 0,3 & 0,4 & 12 & 12 & 1,5 & $0,4 \quad 0,7$ & - & 2 & - & $20 \quad 30$ & 150 & - & -5 \\
\hline Sam. & $\begin{array}{lll}10-2 & 10-3\end{array}$ & $10-31$ & $10-3$ & $10-3$ & 10-3 & $10-3$ & $10-2 \quad 10-1$ & $10-1$ & $10-4$ & $10-2$ & $10-210-3$ & $310-2$ & $10-10$ & \begin{tabular}{|l|lll}
3 & $10-3$ & $10-3$
\end{tabular} \\
\hline no. & $\mathrm{Cd} \quad \mathrm{Sn}$ & $\mathrm{Ge}$ & $\mathrm{Ga}$ & In & $\mathbf{Y b}$ & $\mathbf{Y}$ & $\mathrm{La} \quad \mathrm{Ce}$ & $P$ & $\mathrm{Be}$ & $\mathrm{Sr}$ & $\mathrm{B} \mathrm{a} \mathrm{Li}$ & Th & U Pt & $\mathrm{Au} \quad \mathrm{Sc}$ \\
\hline $\mathrm{CF}$ & $-0,2$ & - & - & - & 0,4 & 5 & - & - & - & 2 & - & - & $\cdots$ & - \\
\hline $\mathrm{SF}$ & - 0,4 & - & - & - & 0,5 & 5 & - & - & - & 2 & - & - & $\cdots$ & - \\
\hline Sam. & & & & & & & & & & $\mathrm{iO}_{2} \mathrm{Al}$ & $\mathrm{O}_{3} \mathrm{MgO}$ & $\mathrm{Fe}_{2} \mathrm{O}_{3}$ & ${ }_{3} \mathrm{CaO}$ & $\mathrm{Na}_{2} \mathrm{O} \mathrm{K}_{2} \mathrm{O}$ \\
\hline no. & & & & & & & & & & & & $\%$ & & \\
\hline CF & & & & & & & & & & 500,1 & $2-$ & 7 & 0,12 & $0,12-$ \\
\hline $\mathrm{SF}$ & & & & & & & & & & $50 \quad 0,2$ & 0,12 & 7 & 0,2 & $0,12-$ \\
\hline
\end{tabular}

In comparing data of spectral analysis, initial samples, (115-L and 116-L) (Table 1), coarse samples (LT-HF) and fine fractions (LTCMP) (Table 2), some metals are only found in the finely dispersed sample, H: Mn, Co, W, Hb, Ag, Sn, Yb, Y.Moreover other metals $(\mathrm{Ni}, \mathrm{Ti}, \mathrm{Cr}, \mathrm{Cu}, \mathrm{Pb}, \mathrm{Zn}$.) have been shown to increase in fine milling.

\section{Conclusion}

1. The impacts achieved suggestthat the electron morphological analysis suggest that the examined ore refers to moderately magnetic minerals, the mineral texture is massive and the structure is latent crystal.

2. According to the resultsof the the spectral analysis we may point out that, the size of the dispersed particles impacts the expression of some metals (Mn, Co, W, Hb, Ag, Sn, Yb, Y).

3. Provisional data assign that the metal content of fine samples is several times higher than that of coarse grinding samples.

4. The availability of a wide range elements shown in the lyddite sample. 


\section{References}

1. Features of the formation and platinum-metal content of carbonaceoussiliceous shales, lidites of the Berkut rare metal deposits, issues of their complex use / Dzharatov A., Baytukenova N.O., Toktosunova BB, Toktobaeva Ch.K., Batrakeeva G.E., Mukambetova G .J. // Izvestia KSTU im. I. Razzakov. - No. 14. - Bishkek, 2008. - P.213-216.

2. Dzharatov A. Features of the geological structure, formation conditions and minerals of the Lower Paleozoic sediments of the upper reaches of the Chatkal and Saryjaz rivers (Middle Tien Shan). - Author's abstract. Cand. diss., Frunze, 1986.

3. Preliminary data show that the content of metals in finely dispersed samples is several times increased in comparison with coarsely ground samples.

4. Sozinov N.A. Platinoids in black shales [Text] / Sozinov N.A., Ermolaev N.P., Chinyonov V.A. et al. // Nature. 1997.- No. 8. - C.11-17.

5. Application of lidite as refractories. No. 1167. / Vinogradov V.V., Sulaimankulov K.S. et al. // The patent is registered in the State Register of Inventions of the Kyrgyz Republic from 30.06.2009.

6. Unconventional mineral sources of palladium and some other platinoids, problems of their complex extraction / Sulaimankulov KS, Bleshinsky SV, Dzharatov A. et al. // Modern technologies and quality management in education, science and production: experience of adaptation and implementation. Mater. int. scientific. conf. - Bishkek, 2001. - Ch.III.- P.104-109.

7. Kozhogulov K. Ch. Geomechanical problems of the development of ore deposits in the Kyrgyz Republic. g. Mining information and analytical bulletin (scientific and technical journal). Issue No. 12. -Vol. 9. - 2007.

8. Scanning electron microscope. Teaching aid for students of the Faculty of Physics and Technology / Compiled by V.P. Makarov, O.N. Kanygina. KyrgyzRussian Slavic University. Bishkek, 2006 .-- 25 p.

9. Neradovsky Yu.N. Ore Mineragraphy: Textbook for direction 130100 "Geology and Exploration of Mineral Resources" / Yu.N. Nedarovsky. Murmansk: MSTU Publishing House, 2009.- 76 p.

10. Portnov V.S. Optimization of refractory ore crushing process [Text] VS Portnov, VM Yurov, AK Tursunbaeva. et al. // Fundamental research. No. 9.- 2012. - pp. 167-170.

11. Baksheeva I.I. Development of physical and chemical methods of preparation of mineral raw materials for enrichment [Text]: dis. ... Cand. tech. Sciences: 25.00.13: Krasnoyarsk - 2014.

12. Minkina I.I. Logistic management of the process of extracting rare earth metals from apatite ore of the Kola Peninsula. Advancesinchemistryandchemicaltechnology. VolumeXXVII. - 2013. - N9. 